\title{
The Use of Erythropoietin in Liver Regeneration in Pigs after Partial Hepatectomy
}

\author{
Henrique de Aguiar Wiederkehr ${ }^{1 *}$, Caroline Aragão de Carvalho' ${ }^{1}$, Julio Cesar Wiederkehr², \\ Ricardo Ribeiro Gama ${ }^{3}$, Eros Luiz de Sousa ${ }^{4}$, Teresa Cristina Cavalcanti ${ }^{5}$, Taíse Fuchs ${ }^{6}$, \\ Barbara de Aguiar Wiederkehr ${ }^{1}$, Lucas Mansano Sarquis ${ }^{1}$ \\ ${ }^{1}$ Faculdade Evangélica do Paraná, Curitiba, Paraná, Brazil \\ ${ }^{2}$ Department of Surgery, Federal University of Paraná, Curitiba, Paraná, Brazil \\ ${ }^{3}$ Department of Experimental Surgery, Faculdade Evangélica do Paraná, Curitiba, Paraná, Brazil \\ ${ }^{4}$ Department of Veterinary Medicine, Faculdade Evangélica do Paraná, Curitiba, Paraná, Brazil \\ ${ }^{5}$ Department of Pathology, Federal University of Paraná, Curitiba, Paraná, Brazil \\ ${ }^{6}$ Department of Veterinary Anesthesiology, Faculdade Evangélica do Paraná, Curitiba, Paraná, Brazil \\ Email: *Henrique.wie@hotmail.com
}

Received 29 September 2015; accepted 21 November 2015; published 24 November 2015

Copyright (C) 2015 by authors and Scientific Research Publishing Inc.

This work is licensed under the Creative Commons Attribution International License (CC BY).

http://creativecommons.org/licenses/by/4.0/

cC) $\underset{\text { EY }}{ }$ Open Access

\section{Abstract}

A partial hepatectomy is a surgical procedure performed during the living-donor liver transplantation and sometimes the only option for patients with hepatocarcinoma. However the remnant liver after the hepatectomy is still a major concern. Therefore, the process of liver regeneration has been a constant theme of study in order to optimize this process. Erythropoietin, a hormone produced by the kidney and involved in protecting organs like heart, liver and kidney itself against injuries can be one of these factors that could accelerate the liver regeneration. This study aims to observe if erythropoietin can accelerate the process of liver regeneration after partial hepatectomy in pigs. Methods: 8 pigs were classified into 2 groups of 4 pigs each: the control group and the test group. The animals in the first group underwent an application of saline solution subcutaneous on the day before the hepatectomy. Instead of saline solution, the test groups received a subcutaneous injection of $200 \mathrm{UI} / \mathrm{lg}$ of recombinant erythropoietin also on the day before the surgical procedure. After 7 days since the hepatectomy, in each animal the liver was biopsied in two regions, one next to the hepatectomy section and other far from it. The liver regeneration was analyzed using Ki-67. Results: Pigs from control group presented the following results: Control pig I: $30 \%$ of regeneration in the hepatectomy section and $10 \%$ in the region far from it; control pig II $24 \%$ and $4 \%$; control pig III $27 \%$ and $7 \%$. The test group presented no significant liver regenera-

\footnotetext{
${ }^{*}$ Corresponding author.
}

How to cite this paper: Wiederkehr, H.A., de Carvalho, C.A., Wiederkehr, J.C., Gama, R.R., de Sousa, E.L., Cavalcanti, T.C., Fuchs, T., Wiederkehr, B.A. and Sarquis, L.M. (2015) The Use of Erythropoietin in Liver Regeneration in Pigs after Partial Hepatectomy. Surgical Science, 6, 518-526. http://dx.doi.org/10.4236/ss.2015.611074 
tion since Ki-67 could not identify cell proliferation in neither the biopsied areas. Conclusion: Since the number of pigs was not statistically significant, we could not conclude any further hypothesis. We strong believe that enhancing the number of pigs and testing different doses, we will be able to reach further conclusions.

\section{Keywords}

\section{Liver Regeneration, Partial Hepatectomy, Erythropoietin, Pigs}

\section{Introduction}

One of the distinctive and unique characteristics of the liver is its regenerative ability [1]. Partial hepatic resection is many times the only option for patients suffering with hepatocellular carcinoma and is a procedure frequently used in living-donor liver transplants. However, this resection is limited by the need to preserve a sufficient amount of functional liver tissue, since excessive resection may lead to liver failure just a few days after the surgical procedure [2]-[4].

The greater understanding of the mechanisms responsible for liver regeneration has allowed for the development of various strategies that seek to optimize liver regeneration, thus avoiding liver failure. A two-stage hepatectomy and the emoblization of the vena cava post-operatively are the approaches most commonly used in this case [5]. In keeping with this objective, many experimental studies have been conducted to try and identify substances that can act upon these mechanisms, leveraging the proliferation of the hepatocytes and minimizing the factors that can hinder regeneration.

One of the substances recently studied is erythropoietin (EPO), a glycoprotein growth factor, which corresponds to a primary stimulus for erythropoiesis, promoting the terminal differentiation of the undifferentiated myelin cell in normoblasts and then erythrocytes [6].

The kidneys produce nearly $90 \%$ of all erythropoietin, where interstitial fibroblasts are related to their greater production, with the remaining amount being produced mostly in the liver [7] [8].

However, many studies relate the tubular proximal kidney cells with the production of erythropoietin [9]. This pleiotropic cytokine, known for its role in the stimulation of erythropoiesis, was recently discovered as a powerful agent protecting various tissues against lesions, including the heart, the liver and the kidney [5] [10]-[14]. Its importance was proven in patients with chronic kidney failure, who usually have anemia due primarily to the reduction in erythropoietin production, a consequence of the smaller number of active kidney cells [15] [16]. Besides its multiple anti-apoptotic and anti-oxidant effects, as well as its angiogenic properties, EPO showed a neuro-protective effect against ischemia in cell cultures and in animal models [17] [18]. Therefore, administering EPO before possible injuries to the liver may be advantageous in regard to reducing the ischemia and stimulating cellular regeneration.

A partial hepatectomy is the most powerful stimulant of liver regeneration. After a resection of nearly $70 \%$ or even a massive resection (90\%), nearly $90 \%$ of the remaining hepatocytes are replicated [19] [20].

The post-hepatectomy liver regeneration is the result of a series of complex events regulated by many growth factors and cytokines [19]-[21]. Signal mechanisms and transcriptional factors such as the nuclear factor-kappa $\mathrm{B}(\mathrm{NF}-\mathrm{kB})$ and intracellular mechanisms that involve mitogen-activated protein kinases, necessary for cellular survival and proliferation, are quickly activated in the remaining liver tissue after a partial hepatectomy [22].

In detail, the phosphorylated extracellular signal-regulated kinases (pERKS), c-Jun N-terminal kinase (JNK) and tyrosine kinase receptors promote stimuli and the initial signals of the liver regeneration process [23]-[26]. However, evidence of EPO influence in apoptosis reduction is still controversial [27]-[29].

This study aims to verify the protective role of erythropoietin in liver regeneration after partial hepatectomy in pigs and its influence in the optimization of this process.

\section{Methods}

The research was carried out in the Advanced Veterinary Medicine Practice Laboratory facilities at the Faculdade Evangélica do Paraná located in the Palmeira municipality, at the Witmarsum Colony, connected to the 
Faculdade Evangélica do Paraná. Also, this research was approved by the animal ethical committee on 05/22/ 2013 under the number 004101/2013 according to the Brazilian law 6638 referring to medical researches in animals.

The animals used were Large White pigs (acquired by the laboratory where the study was conducted), with an approximate age of 3 months and weighing $20 \mathrm{~kg}$. The sample used in this study was made up of 8 animals, divided into 2 groups: the control group had 4 animals and the test group also with 4 animals. The animal in the control group was submitted to a subcutaneous injection of $0.9 \%$ saline solution, $\mathrm{NaCl}$, the day before the hepatectomy. The test group received a subcutaneous injection of $200 \mathrm{UI} / \mathrm{kg}$ of $40.000 \mathrm{UI} / \mathrm{ml}$ (Eritromax ${ }^{\circledR}$-Blausiegel) recombinant erythpoietin, also one day prior to the hepatectomy.

The animals were accommodated in stalls at the FEPAR Animal Health Unit II with water ad libitum, fed with commercial grade feed which was balanced and age-appropriate, without any additional lipid supplementation. The animals arrived at the location 10 days prior to the procedure, which allowed for a proper environmental adaptation.

The pigs were chosen basically for two reasons, first of all, according to the Advisor's experience with surgery in pigs, as well as their size, which allowed an easy manipulation of the liver.

Second, they are a more sturdy type of animal, with a physiology that is similar to that of humans, meaning the laboratory handling would be safer.

The animals were submitted to a 12-hour fast for solid foods and 4 hours for liquids. The technique used was generalized inhalatio anesthesia, using a closed system.

The pre-anesthetic medication was composed of Acempromazine $(0.05 \mathrm{mg} / \mathrm{kg})$; Ketamine $(10 \mathrm{mg} / \mathrm{kg})$; and Midazolam $(0.5 \mathrm{mg} / \mathrm{kg})$. The anesthetic induction included Thiopental $(12.5 \mathrm{mg} / \mathrm{kg})$ and was maintained by Isoflurane.

During the trans-operative period, the analgesia control consisted of a $30 \mathrm{mg}$ morphine infusion, along with $30 \mathrm{mg}$ of Ketamine and $150 \mathrm{mg}$ of Lidocaine, with a $10 \mathrm{ml} / \mathrm{kg} /$ hour infusion rate.

During the post-operative stage, the animal was administered a $7 \mathrm{mg} / \mathrm{kg}$ dose of Tramadol every 8 hours, along with $1 \mathrm{mg} / \mathrm{kg}$ of Ketoprofene every 24 hours. The antibiotic chosen was Ceftiofur, with a $30 \mathrm{mg} / \mathrm{kg}$ dose every 12 hours, administered during 5 days. A $250 \mathrm{ml}$ dose of a combination of multivitamins and glucose was also administered to each animal immediately after the surgery.

On day 1 of the experiment, the control group animals received a $10 \mathrm{ml}$ subcutaneous injection of $0.9 \% \mathrm{NaCl}$ saline solution the day prior to the experiment.

On day 2 of the experiment, the control group animals were submitted to a hepatectomy of approximately $65 \%$ of the total liver volume, based on the "Partial hepatectomy and liver regeneration in pigs-the response to different resection sizes" study, published in The Journal of Surgical Research [30].

Under antiseptic surgical conditions, after a median xifopubic laparotomy and the division of the hepatic ligaments, the isolation and ligature of the portal vein branches to the lateral and medial segments of the left lobe of the liver were carried out. A 0 cotton suture was tied around the base of lateral segment of the left lobe and the lobe was then excised. Hemostasis was controlled by coagulation cautery. Then, the same procedure was carried out in the medial segment of the left lobe.

Seven days post-hepatectomy, liver samples were taken from the control group animals. Two samples were taken from each animal, one at the hepatectomy resection site and another from an area away from the surgical procedure site, for posterior anatomopathological and immunohistochemical evaluation. The animals were then euthanized with an anesthetic overdose using a $50 \mathrm{mg} / \mathrm{kg}$ Thiopental intravenous dose (more than three times the dose used for anesthetic induction, as recommended by the Brazilian guide for best practices in animal euthanasia).

On this same day, the three animals in the test group, which had received a $200 \mathrm{UI} / \mathrm{kg}$ intraperitoneal injection of recombinant erythropoietin the day prior to the procedure, were submitted to the same hepatectomy performed on the control group, without any alterations.

Finally, on the 15th day of the study, samples were taken from the test group, following the same procedures used for the samples taken previously from the animals in the control group, and these were then euthanized through an anesthetic overdose of Thiopental.

The samples taken from the pig livers were stored in a $10 \%$ formaldehyde solution for posterior embedding into paraffin blocks and immunohistochemical evaluation.

The levels of cellular proliferation in the study were measured using a KI-67 monoclonal antibody through an 
immunohistochemical analysis. The KI-67 (pKI-67) nuclear protein is considered to be expressed exclusively in proliferating cells, in other words, during the active stage of cellular division. This strict correlation between cell proliferation and pKi-67 makes this protein an excellent marker for determining the growth of a specific cellular population and therefore is widely used in the investigation of proliferative cellular patterns [31]-[33].

The method for obtaining the immunohistochemical staining of the paraffin cuts and the expression of the markers studied came from CITOLAB (Laboratório de Citologia e Histopatologia Ltda.), laboratory in Curitiba.

All the sections received immunohistochemical treatment with the ki-67 marker, following the CITOLAB protocol and were then analyzed by pathologists.

The preparation included two stages in two days. The first was dewaxing, followed by antigen retrieval, blocking of endogenous peroxidase and incubation of the sections with primary antibodies overnight. On the second day, the next stage was carried out with the incubation of the secondary antibody (biotin) for 30 minutes (yellow color) and after that Streptavidin incubation immersed in buffered solution for 30 more minutes (red color). Next, the section will receive DAB-Diaminobenzidine, a chromogen or a substance that takes on a brownish hue in the reaction tree, after bonding with the Streptavidin. The Streptavidin remains bonded to the biotin (secondary antibody), which in turn remains bonded to the primary antibody. This reaction provides the colors to be studied by the computerized system, creating yet a new stain with Hematoxylin in order to contrast compared to the section background, improving visualization. Only then will the samples be mounted for reading by pathologists.

In this study the marker for ki67 was used, which stains cellular proliferation through an immunological reaction to a specific antibody. The antibody used was the anti-KI-67 antibody, IgG type, derived from rat plasma in a $200 \mu / \mathrm{ml}$ (QBEnd/10 LAB-VISION clone).

The analysis of the sections was examiner dependent with a trained professional and was based on the amount nuclei marked with KI-67, in other words, proliferating hepatocyte nuclei, in order to determine the percentage of liver regeneration. The Image J 1.46r (Wayne Rasband National Institutes of Health, USA) software was also used for a quantitative analysis of the marked areas.

\section{Results}

Two samples from each animal were analyzed, one from the resected area of the liver and another from an area away from the first, totaling 16 histopathology samples. All of the samples were immunolabeled for KI-67.

In the control group pigs, the ratio of nuclei labeled with a brown stain was considered as follows: control animal I resulted in 30\%, control animal II in $24 \%$ and control animal III around $27 \%$, and control animal IV around 25\% also in a visual estimate, without counting, involving various fields (Figure 1 \& Figure 2).

In the sample taken away from the resected area in the control group pigs, the results were: control animal I resulted in 10\%, control animal II in 4\%, control animal III in 7\% and a control animal IV a labeling of around $6 \%$ was observed, relative to the ratio of nuclei observed in proliferation, as represented in Table 1.

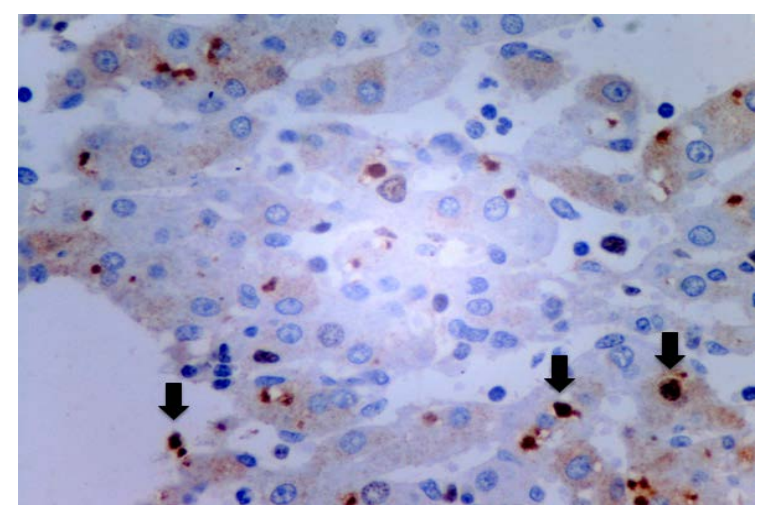

Figure 1. Liver tissue of control animal II taken from resected area, post-hepatectomy, observed with 40× magnification, revealing proliferating nuclei (black arrows), observed through the brown color obtained by the KI-67 immune marker. 


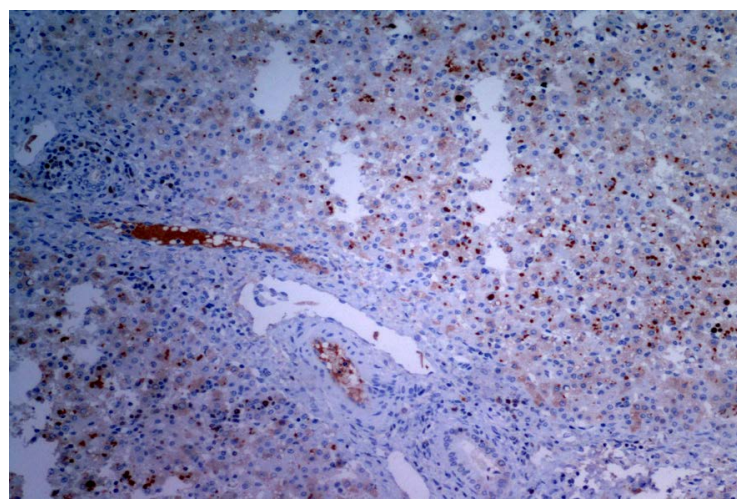

Figure 2. Sample of resected area, post-hepatectomy, in a wide field, showing extensive cellular proliferation represented by the large amount of nuclei marked by KI-67 (nuclei stained in brown) in control animal I.

Table 1. Liver regeneration observed through cellular proliferation analyzed with KI-67.

\begin{tabular}{ccc}
\hline & Within the resected area (\%) & Outside the resected area (\%) \\
\hline Control Animal I & 30 & 10 \\
Control Animal II & 24 & 4 \\
Control Animal III & 27 & 6 \\
Control Animal IV & 25 & 0 \\
Test Animal I & 0 & 0 \\
Test Animal II & 0 & 0 \\
Test Animal III & 0 & 0 \\
Test Animal IV & 0 &
\end{tabular}

Various typical mitoses were observed and many nuclei marked in pairs. These were interpreted as most likely being originated from the mitosis of a precursor cell. In mitoses, the cytoplasm will frequently also be marked by KI-67, forming a type of cloud around the chromosomes.

Among the test group animals the results were similar to those shown in Table 1 . There were practically no nuclei marked by the immunomarker, both in the resected area after the hepatectomy and in the area away from the site (Figure 3 \& Figure 4). Therefore, the result and consequently, the liver regeneration, were interpreted as being insignificant.

It is important to note that no statistical calculation can be made given the low sample size contained in each group.

\section{Discussion}

Situations causing the loss of liver tissue, such as viral diseases, chemical damage and surgical resections, many times can serve as a trigger for the replication of hepatocytes [34]. A broader knowledge of the complex mechanisms involved in liver regeneration may usher in a new era in the treatment of patients with terminal liver failure.

The induction of liver regeneration in liver transplants would help reduce donor morbidity and allow the recipients to experience a faster clinical improvement. Substances that can positively or negatively affect liver regeneration is one of the most attractive topics in modern science [35].

EPO was first defined as a hormone that regulates erythropoiesis in mammals [36]. This substance is also known for its anti-inflammatory, anti-oxidant, anti-apoptotic and angiogenic properties [37].

Bockhorn [37] discovered that different doses of EPO significantly increased liver regeneration and survival in rats submitted to partial hepatectomies and partial liver transplants, however, further studies are necessary in 


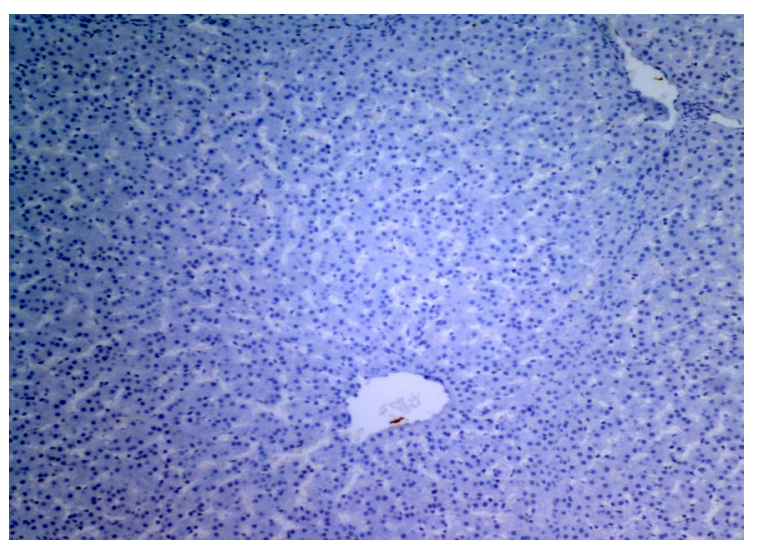

Figure 3. Liver tissue removed from test pig I, outside the resected area post-hepatectomy, showing a lack of nuclei marked by KI-67 immune marker.

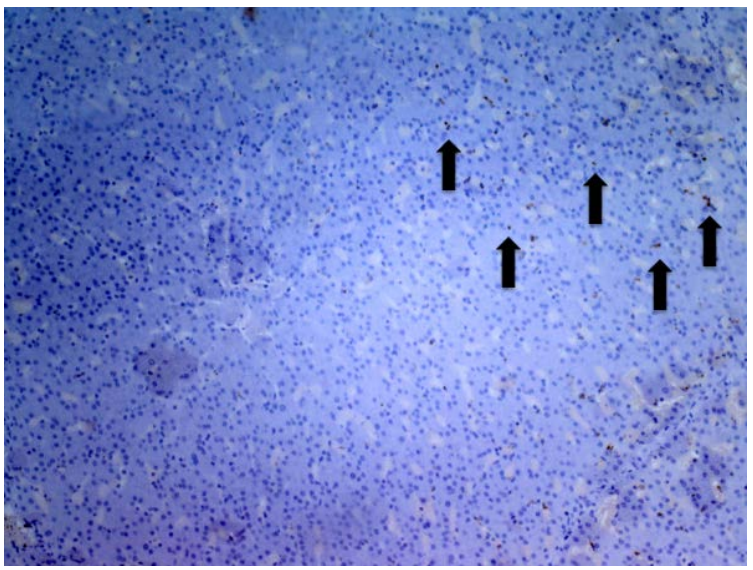

Figure 4. Liver tissue removed from test pig II, from the resected area, post-hepatectomy, revealing a minimal amount of nuclei marked by KI-67 (black arrows).

order to identify the ideal dose.

Klemm [38] discovered that when EPO was administered in multiple doses of 500 and $5000 \mathrm{UI} / \mathrm{kg}$ intravenously, it interrupted liver regeneration.

There are various studies about the method and EPO dosage for use in animals, with some suggesting 3.000 UI of EPO/kg subcutaneously [1], 4.000 (UI of EPO/kg intraperitoneal [10]. This study showed that a dose of $200 \mathrm{UI} \mathrm{EPO} / \mathrm{kg}$ subcutaneously, in spite of being considered a low dose, significantly reduced the regenerative ability of the remaining tissue after liver resection.

Knowing that a dose of $5.000 \mathrm{UI} / \mathrm{kg}$ of body weight is high when compared to the dose used for the treatment of anemia (10 - $15 \mathrm{UI} / \mathrm{kg})$, the fact that similar doses have been used experimentally to exert cytoprotective effects on non-hematopoietic cells must be taken into consideration [39]. A dosage of $5.000 \mathrm{UI} / \mathrm{kg}$ in rodents is comparable to a dose of nearly $500 \mathrm{IU} / \mathrm{kg}$, tested on humans in a small clinical course [40], taking into account the different weight-surface ratio. However, comparative studies between rodents and mid-sized animals are still needed, such as the ones used in this experiment.

The reduced liver regeneration shows discrepancies with a study published by Schmeding et al. showing that the intraportal administration of EPO before the resection or a subcutaneous injection during 3 days after the surgery does in fact increase liver regeneration in rats after a 70\% resection [41]. The Klemm [38] study on the other hand, presented concurring results regarding the negative influence of low erythropoietin doses in liver regeneration. However, there are various discrepancies such animal models, administration mode, among others, in the current study as well as in Klemm's, making comparisons difficult. 
The preference for using pigs instead of other animals, such as rats, rabbits or even sheep, is based mainly on the similaraties between pig and human gastrointestinal and endocrine systems. Another factor is that since it is a larger animal, it offers many advantages, such as the variety of sites from which blood and tissue samples can be collected [42], therefore these animals can be studied and followed in a sequenced manner, without any significant harm to the well-being of the animal.

Thus, researchers can still follow and describe the sequential and morphological changes in order to understand the liver regeneration mechanism and its activity factors, such as thymidien kinase [42]-[44].

Once the animal is chosen, an important part of the project to be discussed is the surgical technique. Even with the best liver regeneration index being reached with $70 \%$ resection of the liver tissue, according to model presented by Kahn and collaborators [30], the chosen technique for this model was a $65 \%$ partial hepatectomy, due to the shorter surgical period and reduced blood loss, making the surgery safer.

The technique consists of disecting the portal vein and ligating its branches and the branches of the left hepatic artery in the lateral and medial segments of the left lobe of the animal's liver. These two lobes are then resected using the "crushing" technique in which the lobes are manually removed, with the use of the surgeon's fingers to separate the liver parenchyma.

In this study, however, we modified the technique and used electric cautery to divulse the liver tissue and apply mechanical stimulation to promote liver regeneration.

\section{Conclusions}

This study was important in order to establish an evaluation model for liver regeneration in pigs, especially related to the use of Ki-67 in liver tissue in pigs, which proved to be an effective and reliable immune marker.

As this was a pilot project, the conclusion is only that future studies are required in order to better understand the liver regeneration process and the influence exerted by erythropoietin in this process.

We believe that with a larger sample number and the creation of animal groups with different doses, further exploration and discoveries related to this topic will be made possible.

\section{References}

[1] Gul, M., Cömert, M., Çakmak, G.K., Kertis, G., Ugurbas, E. and Oner, M.O. (2013) Effect of Erythropoietin on Liver Regeneration in an Experimental Model of Partial Hepatectomy. International Journal of Surgery (London, England), 11, 59-63.

[2] Belghiti, J., Hiramatsu, K., Benoist, S., Massault, P., Sauvanet, A. and Farges, O. (2000) Seven Hundred Forty-Seven Hepatectomies in the 1990s: An Update to Evaluate the Actual Risk of Liver Resection. Journal of the American College of Surgeons, 191, 38-46. http://dx.doi.org/10.1016/S1072-7515(00)00261-1

[3] Jarnagin, W.R., Gonen, M., Fong, Y., DeMatteo, R.P., Ben-Porat, L., Little, S., Corvera, C., Weber, S. and Blumgart, L.H. (2002) Improvement in Peri-Operative Outcome after Hepatic Resection: Analysis of 1,803 Consecutive Cases over the Past Decade. Annals of Surgery, 236, 397-406. http://dx.doi.org/10.1097/00000658-200210000-00001

[4] Garcea, G. and Maddern, G.J. (2009) Liver Failure after Major Hepatic Resection. Journal of Hepato-Biliary-Pancreatic Surgery, 16, 145-155. http://dx.doi.org/10.1007/s00534-008-0017-y

[5] Liu, X., Xie, W., Liu, P., Duan, M., Jia, Z., Li, W. and Xu, J. (2006) Mechanism of Cardioprotection of rhEPO Pretreatment on Suppressing the Inflammatory Response in Ischemia-Reperfusion. Life Sciences, 78, 2255-2264. http://dx.doi.org/10.1016/j.lfs.2005.09.053

[6] Bennett, C.L., Cournoyer, D., Carson, K.R., Rossert, J., Luminari, S., Evens, A.M., Locatelli, F., Belknap, S.M., McKoy, J.M., Lyons, E.A., Kim, B., Sharma, R., Costelo, S., Toffelmire, E.B., Wells, G.A., Messner, H.A., Yarnold, P.R., Trifilio, S.M., Raisch, D.W., Kuzel, T.M., Nissenson, A., Lim, L.C., Tallman, M.S. and Casadevall, N. (2005) Long-Term Outcome of Individuals With Pure Red Cell Aplasia and Antierythropoietin Antibodies in Patients Treated With Recombinant Epoetin: A Follow-Up Report from the Research on Adverse Drug Events and Reports (RADAR). Project. Blood, 106, 3343-3347. http://dx.doi.org/10.1182/blood-2005-02-0508

[7] Cohen, V., Jellinek, S.P., Teperikidis, L., Berkovits, E. and Goldman, W.M. (2007) Room-Temperature Storage of Medications Labeled for Refrigeration. American Journal of Health-System Pharmacy, 64, 1711-1715. http://dx.doi.org/10.2146/ajhp060262

[8] Corbo, D.C., Suddith, R.L., Sharma, B. and Naso, R.B. (1992) Stability, Potency, and Preservative Effectiveness of Epoetin Alfa after Addition of a Bacteriostatic Diluent. American Journal of Hospital Pharmacy, 49, 1455-1458.

[9] Corwin, H.L., Gettinger, A., Fabian, T.C., May, A., Pearl, R.G., Heard, S., An, R., Bowers, P.J., Burton, P., Klausner, 
M.A. and Corwin, M.J. (2007) Efficacy and Safety of Epoetin Alfa in Critically Ill Patients. The New England Journal of Medicine, 357, 965-976.

[10] Greif, F., Ben-Ari, Z., Taya, R., Pappo, O., Kurtzwald, E., Cheporko, Y., Ravid, A. and Hochhauser, E. (2010) Dual Effect of Erythropoietin on Liver Protection and Regeneration after Subtotal Hepatectomy in Rats. Liver Transplantation, 16, 631-638.

[11] Lewis, L.D. (2004) Preclinical and Clinical Studies: A Preview of Potential Future Applications of Erythropoietic Agents. Seminars in Hematology, 41, 17-25. http://dx.doi.org/10.1053/j.seminhematol.2004.09.004

[12] Bogoyevitch, M.A. (2004) An Update on the Cardiac Effects of Erythropoietin Cardioprotection by Erythropoietin and the Lessons Learnt from Studies in Neuroprotection. Cardiovascular Research, 63, 208-216. http://dx.doi.org/10.1016/j.cardiores.2004.03.017

[13] Yang, C.W., Li, C., Jung, J.Y., Shin, S.J., Choi, B.S., Lim, S.W., Sun, B.K., Kim, Y.S., Kim, J., Chang, Y.S. and Bang, B.K. (2003) Preconditioning with Erythropoietin Protects against Subsequent Ischemia-Reperfusion Injury in Rat Kidney. FASEB Journal, 17, 1754-1755.

[14] Calvillo, L., Latini, R., Kajstura, J., Leri, A., Anversa, P., Ghezzi, P., Salio, M., Cerami, A. and Brines, M. (2003) Recombinant Human Erythropoietin Protects the Myocardium from Ischemia-Reperfusion Injury and Promotes Beneficial Remodeling. Proceedings of the National Academy of Sciences of the United States of America, 100, 4802-4806. http://dx.doi.org/10.1073/pnas.0630444100

[15] Erslev, A.J. (1991) Erythropoietin. New England Journal of Medicine, 324, 1339-1344. http://dx.doi.org/10.1056/NEJM199105093241907

[16] Eschbach, J.W., Egrie, J.C., Downing, M.R., Browne, J.K. and Adamson, J.W. (1987) Correction of the Anemia of End-Stage Renal Disease with Recombinant Human Erythropoietin. Results of a Combined Phase I and II Clinical Trial. New England Journal of Medicine, 316, 73-78. http://dx.doi.org/10.1056/NEJM198701083160203

[17] Siren, A.L. and Ehrenreich, H. (2001) Erythropoietin-A Novel Concept for Neuroprotection. European Archives of Psychiatry and Clinical Neuroscience, 251, 179-184. http://dx.doi.org/10.1007/s004060170038

[18] Grasso, G. (2001) Neuroprotective Effect of Recombinant Human Erythropoietin in Experimental Subarachnoid Hemorrahage. Journal of Neurosurgery, 45, 7-14.

[19] Taub, R. (2004) Liver Regeneration: From Myth to Mechanism. Nature Reviews Molecular Cell Biology, 5, $836-847$. http://dx.doi.org/10.1038/nrm1489

[20] Clavien, P.A., Petrowsky, H., De Oliveira, M.L. and Graf, R. (2007) Strategies for Safer Liver Surgery and Partial Liver Transplantation. New England Journal of Medicine, 356, 1545-1559. http://dx.doi.org/10.1056/NEJMra065156

[21] Taub, R., Greenbaum, L.E. and Peng, Y. (1999) Transcriptional Regulatory Signals Define Cytokine-Dependent and Independent Pathways in Liver Regeneration. Seminars in Liver Disease, 19, 117-127. http://dx.doi.org/10.1055/s-2007-1007104

[22] Greif, F., Ben-Ari, Z., Taya, R., Pappo, O., Kurtzwald, E., Cheporko, Y., Ravid, A. and Hochhauser, E. (2010) Dual Effect of Erythropoietin on Liver Protection and Regeneration after Subtotal Hepatectomy in Rats. Liver Transplantation: Official Publication of the American Association for the Study of Liver Diseases and the International Liver Transplantation Society, 16, 631-638. http://dx.doi.org/10.1002/lt.22046

[23] Schwabe, R.F., Bradham, C.A., Uehara, T., Hatano, E., Bennett, B.L., Schoonhoven, R. and Brenner, D.A. (2003) c-Jun-N-Terminal Kinase Drives Cyclin D1 Expression and Proliferation during Liver Regeneration. Hepatology, 37, 824-832. http://dx.doi.org/10.1053/jhep.2003.50135

[24] Luedde, T., Rodriguez, M.E., Tacke, F., Xiong, Y., Brenner, D.A. and Trautwein, C. (2003) p18INK4c Collaborates with Other CDK Inhibitory Proteins in the Regenerating Liver. Hepatology, 37, 833-841. http://dx.doi.org/10.1053/jhep.2003.50136

[25] Behrens, A., Sibilia, M., David, J.P., Möhle-Steinlein, U., Tronche, F., Schütz, G. and Wagner, E.F. (2002) Impaired Postnatal Hepatocyte Proliferation and Liver Regeneration in Mice Lacking c-Jun in the Liver. The EMBO Journal, 21, 1782-1790. http://dx.doi.org/10.1093/emboj/21.7.1782

[26] Talarmin, H., Rescan, C., Cariou, S., Glaise, D., Zanninelli, G., Bilodeau, M., Loyer, P., Guguen-Guillouzo, C. and Baffet, G. (1999) The Mitogen-Activated Protein Kinase Kinase/Extracellular Signal-Regulated Kinase Cascade Activation Is a Key Signaling Pathway Involved in the Regulation of $\mathrm{G}_{1}$ Phase Progression in Proliferating Hepatocytes. Molecular and Cellular Biology, 19, 6003-6011. http://dx.doi.org/10.1128/MCB.19.9.6003

[27] Sakamoto, T., Liu, Z., Murase, N., Ezure, T., Yokomuro, S., Poli, V. and Demetris, A.J. (1999) Mitosis and Apoptosis in the Liver of Interleukin-6-Deficient Mice after Partial Hepatectomy. Hepatology, 29, 403-411. http://dx.doi.org/10.1002/hep.510290244

[28] Yoshida, N., Iwata, H., Yamada, T., Sekino, T., Matsuo, H., Shirahashi, K., Miyahara, T., Kiyama, S. and Takemura, H. (2007) Improvement of the Survival Rate after Rat Massive Hepatectomy Due to the Reduction of Apoptosis by Cas- 
pase Inhibitor. Journal of Gastroenterology and Hepatology, 22, 2015-2021. http://dx.doi.org/10.1111/j.1440-1746.2007.04960.x

[29] Neuman, M.G. (2001) Apoptosis in Diseases of the Liver. Critical Reviews in Clinical Laboratory Sciences, 38, 109166. http://dx.doi.org/10.1080/20014091084182

[30] Kahn, D., Hickman, R., Terblanche, J. and von Sommoggy, S. (1988) Partial Hepatectomy and Liver Regeneration in Pigs-The Response to Different Resection Sizes. The Journal of Surgical Research, 45, 176-180. http://dx.doi.org/10.1016/0022-4804(88)90062-5

[31] Bullwinkel, J., Baron-Lühr, B., Lüdemann, A., Wohlenberg, C., Gerdes, J. and Scholzen, T. (2006) Ki-67 Protein Is Associated with Ribosomal RNA Transcription in Quiescent and Proliferating Cells. Journal of Cellular Physiology, 206, 624-635. http://dx.doi.org/10.1002/jcp.20494

[32] Koskinas, J., Petraki, K., Kavantzas, N., Rapti, I., Kountouras, D. and Hadziyannis, S. (2005) Hepatic Expression of the Proliferative Marker Ki-67 and p53 Protein in HBV or HCV Cirrhosis in Relation to Dysplastic Liver Cell Changes and Hepatocellular Carcinoma. Journal of Viral Hepatitis, 12, 635-641. http://dx.doi.org/10.1111/j.1365-2893.2005.00635.x

[33] Schmidt, M., Broll, R., Bruch, H. and Duchrow, M. (2002) The Proliferation Marker pKi-67 Becomes Masked to MIB-1 Staining after Expression of Its Tandem Repeats. Histochemistry and Cell Biology, 118, 415-422. http://dx.doi.org/10.1007/s00418-002-0464-5

[34] Humar, A., Kosari, K., Sielaff, T.D., Glessing, B., Gomes, M., Dietz, C., Rosen, G., Lake, J. and Payne, W.D. (2004) Liver Regeneration after Adult Living Donor and Deceased Donor Split-Liver Transplants. Liver Transplantation, 10, 374-378.

[35] Pahlavan, P.S., Feldmann Jr., R.E., Zavos, C. and Kountouras, J. (2006) Prometheus' Challenge: Molecular, Cellular and Systemic Aspects of Liver Regeneration. Journal of Surgical Research, 134, 238-251.

[36] Savino, R. and Ciliberto, G. (2004) A Paradigm Shift for Erythropoietin: No Longer a Specialized Growth Factor, but Rather an All-Purpose Tissue-Protective Agent. Cell Death \& Differentiation, 11, S2-S4.

[37] Bockhorn, M., Fingas, C.D., Rauen, U., Canbay, A., Sotiropoulos, G.C., Frey, U., Sheu, S.Y., Wohlschläger, J., Broelsch, C.E. and Schlaak, J.F. (2008) Erythropoietin Treatment Improves Liver Regeneration and Survival in Rat Models of Extended Liver Resection and Living Donor Liver Transplantation. Transplantation, 86, 1578-1585.

[38] Klemm, K., Eipel, C., Cantré, D., Abshagen, K., Menger, M.D. and Vollmar, B. (2008) Multiple Doses of Erythropoietin Impair Liver Regeneration by Increasing TNF-Alpha, the Bax to Bcl-xL Ratio and Apoptotic Cell Death. PLoS ONE, 3, e3924. http://dx.doi.org/10.1371/journal.pone.0003924

[39] Katavetin, P., Tungsanga, K., Eiam-Ong, S. and Nangaku, M. (2007) Antioxidative Effects of Erythropoietin. Kidney International, 72, S10-S15. http://dx.doi.org/10.1038/sj.ki.5002482

[40] Ehrenreich, H., Hasselblatt, M., Dembowski, C., Cepek, L., Lewczuk, P., Stiefel, M., Rustenbeck, H.H., Breiter, N., Jacob, S., Knerlich, F., Bohn, M., Poser, W., Rüther, E., Kochen, M., Gefeller, O., Gleiter, C., Wessel, T.C., De Ryck, M., Itri, L., Prange, H., Cerami, A., Brines, M. and Sirén, A.L. (2002) Erythropoietin Therapy for Acute Stroke Is Both Safe and Beneficial. Molecular Medicine, 8, 495-505.

[41] Schmeding, M., Boas-Knoop, S., Lippert, S., Ruehl, M., Somasundaram, R., Dagdelen, T., Neuhaus, P. and Neumann, U.P. (2008) Erythropoietin Promotes Hepatic Regeneration after Extended Liver Resection in Rats. Journal of Gastroenterology and Hepatology, 23, 1125-1131. http://dx.doi.org/10.1111/j.1440-1746.2007.05265.x

[42] Kahn, D., van Hoom-Hickman, R., Child, P. and Terblanche, J. (1984) Transhepatic Changes in Insulin and Glucagon Following Partial Hepatectomy in the Pig: The Effect of Hypoglycemia. Surgery, Gynecology \& Obstetrics, 158, 475.

[43] Kahn, D., Stadler, J., Terblanche, J. and van Hoom-Hickman, R. (1980) Thymidine Kinase: An Inexpensive Index of Liver Regeneration in a Large Animal Model. Gastroenterology, 79, 907-911.

[44] Kahn, D., van Hoorn-Hickman, R. and Terblanche, J. (1984) Liver Blood Flow after Partial Hepatectomy in the Pig. Journal of Surgical Research, 37, 290-294. http://dx.doi.org/10.1016/0022-4804(84)90191-4 